\title{
PENGARUH KONSUMSI BUAH NAGA TERHADAP PERUBAHAN TRIGLISERIDA DAN HDL PADA GURU SEKOLAH MENENGAH DI MAKASSAR
}

\author{
Nur Fitri Ihsan ${ }^{1}$, Nurhaedar Jafar ${ }^{2}$, Andi Nurlinda ${ }^{3}$ \\ 1. Pascasariana Universitas Muslim Indonesia \\ ${ }^{2}$ Universitas Hasanuddin \\ ${ }^{3}$ Universitas Muslim Indonesia
}

Alamat korespondensi: (nurfitriihsan107@gmail.com/085146111074)

\begin{abstract}
ABSTRAK
Peningkatan kolesterol dan lipid darah yang tidak normal meningkatkan risiko serangan jantung dan stroke. Tujuan penelitian ini untuk mengetahui pengaruh konsumsi buah naga terhadap perubahan trigliserida dan HDL pada guru sekolahmemngah di Makassar. Penelitian ini merupakan jenis penelitian quasi eksperimen dengan rancangan pertest dan posttest control grup "Two group pretest-posttest, jumlah sampel sebanyak 13 orang yang di bagi 2 kelompok. Instrumen yang digunakan adalah buah naga, timbangan buah, pemeriksaan trigliserida dan HDL oleh Lab Prodia, lembar kuesioner dan Foof recall. Buah naga yang diberikan untuk dikonsumsi 150-250gram dan dikonsumsi 1 kali perhari. Data dianalisis menggunakan program SPSS dengan uji stastistik Wilcoxon Signed Ranks Test, uji Independent test dan uji mann whitney tingkat kemaknaan $\rho$ Value $<0,05$. Berdasarkan hasil analisis perubahan HDL pada laki-laki sebelum dan sesudah konsumsi buah naga diperoleh nilai $\rho=0,255$ sedangkan HDL perempuan $\rho=1,00$ tidak ada perubahan signifikan antara HDL laki-laki dan perempuan sebelum dan setelah perlakuan. Perubahan pada variable Trigliserida nilai $p=0,717$ berarti tidak ada perbedaan yang signifikan sebelum dan setelah perlakuan. Sedangkan pada uji perbandingan variable HDL pretest kelompok intervensi dan control diperoleh nilai $\rho=0,088$ dan posttest diperoleh nilai $\rho=0,077$ tidak ada perbedaan yang signifikan antara kelompok intervensi dan control. Sedangkan pada variable Trigliserida pretest diperoleh nilai $\rho=0,965$ dan post test diperoleh nilai $\rho=0,689$ berarti tidak ada perbedaan yang signifikan kelompok intervensi dan control. Kesimpulan dalam penelitian ini adalah tidak ada perubahan yang signifikan terhadap HDL dan Trigliserida pada kelompok intervensi sebelum dan sesudah konsumsi buah naga.
\end{abstract}

Kata Kunci: Buah Naga, Trigliserida, $H D L$

\section{PENDAHULUAN}

High-density lipoproteins (HDL), atau kolesterol "baik", membantu menghilangkan kolesterol dari tubuh Anda. Secara umum, semakin tinggi HDL Anda semakin baik (ADA,2017). Trigliserida adalah jenis lemak darah lain yang meningkatkan peluang Anda untuk serangan jantung atau stroke jika kadar anda terlalu tinggi (ADA,2017). Peningkatan kolesterol darah dan lipid darah yang tidak normal meningkatkan risiko serangan jantung dan stroke (WHO 2015). Individu yang berisiko CVD dapat menunjukkan peningkatan tekanan darah, glukosa, dan lipid serta kelebihan berat badan dan obesitas.

Dari 56,9 juta kematian di seluruh dunia pada tahun 2016, lebih dari separuh (54\%) disebabkan oleh 10 penyebab teratas. Penyakit jantung iskemik dan stroke adalah pembunuh terbesar di dunia, yang menyebabkan gabungan 15,22 juta kematian pada tahun 2016. Penyakit ini tetap menjadi penyebab utama kematian secara global dalam 15 tahun terakhir $(\mathrm{WHO}, 2018)$.
Proporsi penduduk $\geq 15$ tahun dengan kadar HDL di bawah nilai normal menurut NCEP-ATP III. Secara keseluruhan didapatkan 22,9 persen penduduk Indonesia memiliki kadar HDL dibawah nilai normal, dan pada laki-laki didapatkan proporsi dua kali lipat lebih $(34,8 \%)$ dibandingkan dengan perempuan (15,3\%) (RISKESDAS,2013).

Prevalensi jantung koroner berdasarkan wawancara terdiagnosis dokter di Indonesia sebesar 0,5 persen, dan berdasarkan terdiagnosis dokter atau gejala sebesar 1,5 persen. Sulawesi Selatan (2,9\%).

Konsumsi buah dan sayuran yang tidak memadai salah satu penyebab CVD (WHO,2003). Buah naga merah (Hylocereus polyrhizus) memiliki potensi untuk mengurangi risiko penyakit kardiovaskular (CVD) dengan meningkatkan kolesterol HDL (HDL-C) dengan agen hipokolesterolemiknya. Ini mengandung konten fenolik total, anthocyanin, betacyanins, vitamin C, flavonoid, dan serat (Nourah,2016).

Berdasarkan uraian diatas, maka peneliti merasa perlu untuk melakukan penelitian pengaruh konsumsi buah naga 
terhadap perubahan kadar trigliserida \& HDL pada guru sekolah mengah di Makassar.

\section{BAHAN DAN METODE}

Lokasi, Populasi, Sampel

Penelitian ini dilaksanakan SMP 19, SMP 8, SMP 12, SMP 30, SMP9, SMA 21 dan SMA 6 di Makassar. Populasi dalam penelitian ini yaitu 145 guru sekolah mengah dari 8 sekolah yang dilakukan pemeriksaan HDL dan Trigliserida oleh penelitian sebelumnya dan dari populasi tersebut terdapat 30 orang guru yang mengalami HDL dan trigliserida yang tidak normal yang kemudian dilakukan screening 22 orang guru dengan jumlah sampel pada penelitian ini adalah 13 orang.

1. Kriteria inklusi:
a. berusia 27-60 tahun
b. guru PNS
c. kadar trigliserida $>150$ dan kadar $\mathrm{HDL}<40$ bagipria dan perempuan $<50$
d. bersedia mengkonsumsi buah naga
e. tidak mengkonsumsi obat penurun kolesterol
f. menandatangani informed consent

2. Kriteria eksklusi:
a. wanita hamil
b. terdiagnosis penyakit jantung, stroke
c. mengkonsumsi obat penurun kolesterol

\section{Pengumpulan Data}

1. Data sekunder adalah data yang diperoleh dalam bentuk jadi dan telah diolah oleh pihak lain yang biasanya dalam bentuk publikasi.

2. Data primer adalah data yang dikumpulkan dan diolah sendiri oleh suatu organisasi atau perorangan langsung dari objeknya (Saryono 2014).

\section{Pengolahan Data}

1. Editing

Editing adalah tahapan kegiatan memeriksa validitas data yang masuk seperti memeriksa kelengkapan pengisian kuesioner, kejelasan jawaban, relevansi jawaban dan keseragaman suatu pengukuran.

2. Coding

Coding adalah tahapan kegiatan mengklasifikasi data dan jawaban menurut kategori masing-masing sehingga memudahkan dalam pengelompokan data.

3. Processing

Processing adalah tahapan kegiatan memproses data agar dapat dianalisis. Pemrosesan data dilakukan dengan cara memasukkan data hasil pengisian kuesioner ke dalam master tabel.
4. Cleaning

Cleaning yaitu tahapan kegiatan pengecekan kembali data yang sudah di masukkan dan melakukan koreksi bila terdapat kesalahan. (Lapau, 2013).

\section{Analisis Data}

1. Analisis Univariat

Digunakan untuk mendeskripsikan variabel penelitian guna memperoleh gambaran atau karakteristik sebelum dilakukan analisi bivariat.

2. Analisis Bivariat

Uji hipotesis (uji normalitas) menggunakan uji shapirowilk. Analisis bivariat yang digunakan untuk mengetahui perubahan dan pengaruh konsumsi buah naga terhadap trigliserida dan HDL yaitu uji uji stastistik Wilcoxon Signed Ranks Test, uji Independent test dan uji mann whitney.

\section{HASIL PENELITIAN}

1. Analisis Univariat

Tabel 1 Distribusi karakteristik responden

\begin{tabular}{|c|c|c|c|c|}
\hline \multirow{3}{*}{ Karakteristik } & \multicolumn{4}{|c|}{ Kelompok } \\
\hline & \multicolumn{2}{|c|}{$\begin{array}{l}\text { Kelompok } \\
\text { Intervensi }\end{array}$} & \multicolumn{2}{|c|}{$\begin{array}{c}\text { Kelompok } \\
\text { Kontrol }\end{array}$} \\
\hline & $\mathrm{n}: 10$ & $\%$ & $\mathrm{n}: 5$ & $\%$ \\
\hline \multicolumn{5}{|l|}{ Umur } \\
\hline $41-50$ & 1 & 10,0 & - & - \\
\hline $51-60$ & 9 & 90,0 & 5 & 100 \\
\hline \multicolumn{5}{|l|}{$\begin{array}{l}\text { Jenis } \\
\text { Kelamin }\end{array}$} \\
\hline Laki-laki & 5 & 50,0 & 1 & 20,0 \\
\hline Perempuan & 5 & 50,0 & 4 & 80,0 \\
\hline \multicolumn{5}{|l|}{ Sekolah } \\
\hline SMP 19 & 4 & 40,0 & - & - \\
\hline SMP 8 & 3 & 30,0 & - & - \\
\hline SMP 30 & 0 & 0 & 2 & 40,0 \\
\hline SMP 9 & 2 & 20,0 & - & - \\
\hline SMP 12 & 1 & 10,0 & - & - \\
\hline SMA 21 & - & - & 2 & 40,0 \\
\hline SMA 6 & - & - & 1 & 20,0 \\
\hline \multicolumn{5}{|l|}{ Suku } \\
\hline jawa & 1 & 10,0 & - & - \\
\hline Bugis & 8 & 80,0 & 3 & 80,0 \\
\hline Makassar & 0 & 0 & 2 & 20,0 \\
\hline Bima & 1 & 10,0 & 0 & 0 \\
\hline
\end{tabular}

Berdasarkan table 1 menunjukkan bahwa proporsi kategori umur tertinggi 5160 tahun yaitu 12 orang (90\%) terendah 41-50 tahun yaitu 1 orang (10\%), jenis kelamin laki-laki sebanyak 5orang $(50 \%)$ dan perempuan 5 orang $(50,0 \%)$ 
kebanyakan suku bugis 8 (80). Pada kelompok control pretest terdapat 5 sampel kemudian pada posttest tersisa 3 sampel diakarenakan 2 sampel lainya lagi sakit akibatnya tidak dapat dilakukan pemeriksaan lanjutan.

Table 2 distribusi status gizi responden berdasarkan IMT dan LP

\begin{tabular}{ccccccccc}
\hline & \multicolumn{4}{c}{ Intervensi } & \multicolumn{4}{c}{ kontrol } \\
\cline { 2 - 8 } Status gizi & pretest & posttest & pretest & postest \\
\cline { 2 - 8 } & $n$ & $\%$ & $n$ & $\%$ & $n$ & $\%$ & $n$ & $\%$ \\
\hline IMT & & & & & & & & \\
Obesitas & 5 & 50,0 & 5 & 50,0 & 1 & 33,3 & 1 & 33,3 \\
Overweight & 2 & 20,0 & 2 & 20,0 & 1 & 33.3 & 1 & 33.3 \\
Normal & 3 & 30,0 & 3 & 30,0 & 1 & 33,3 & 1 & 33,3 \\
\hline Total & 10 & 100 & 10 & 100 & 3 & 100 & 3 & 100 \\
\hline LP & 2 & 20,0 & 2 & 20,0 & 2 & 66,7 & 2 & 66,7 \\
Normal & 2 & 20,0 & 8 & 80,0 & 1 & 33,3 & 1 & 33,3 \\
Obesitas & 8 & 80,0 & 80 & 10 & 3 & 100 & 3 & 100 \\
\hline Total & 10 & 100 & 10 & 100 & 3 & 100 \\
\hline
\end{tabular}

Tabel 2 menunjukkan bahwa dari 10 responden kelompok intervensi pada tahap pre-test dan post test status gizi menurut IMT terdapat yang memiliki status gizi obesitas 5 orang $(50 \%)$, overwieght 2 orang $(20 \%)$ dan normal 3 orang $(30 \%)$. Sedangkan untuk status gizi berdasarkan LP kelompok intervensi pretest dan posttes yang memiliki status gizi normal sebanyak 2 orang $(20 \%)$ dan yang obesitas 8 orang $(80 \%)$.

Table 3 konsumsi buah naga

\begin{tabular}{ccc}
\hline \multirow{2}{*}{$\begin{array}{c}\text { Kepatuhan } \\
\text { kosumsi }(\%)\end{array}$} & \multicolumn{2}{c}{ Intervensi } \\
\cline { 2 - 3 } & $\mathrm{n}$ & $\%$ \\
\hline$>81-100$ & 4 & 40 \\
$71-80$ & 4 & 40 \\
$<70$ & 2 & 20 \\
\hline Total & 10 & 100 \\
\hline
\end{tabular}

Berdasarkan tabel 3 kriteria hubungan menunjukkan bahwa kelompok intervensi yang mengkonsumsi buah naga $>81-100$ terdapat 4 orang $(40 \%),<70$ terdapat 2 orang (20\%), yang di anjurkan untk konsumsi full selama 21 hari.
2. Analisis Bivariat

Tabel 4 distribusi sampel munurut kelompok pretest dan posttest

\begin{tabular}{ccccccccc}
\hline & \multicolumn{4}{c}{ Intervensi } & \multicolumn{4}{c}{ kontrol } \\
\cline { 2 - 9 } Variable & \multicolumn{3}{c}{ pretest } & \multicolumn{2}{c}{ posttest } & pretest & postest \\
\cline { 2 - 9 } & $\mathrm{n}$ & $\%$ & $\mathrm{n}$ & $\%$ & $\mathrm{n}$ & $\%$ & $\mathrm{n}$ & $\%$ \\
\hline HDL (Ik) & & & & & & & & \\
$\begin{array}{c}\text { Tidak normal } \\
\text { normal }\end{array}$ & 4 & 80,0 & 4 & 80,0 & 1 & 100 & 1 & 100 \\
\hline Total & 5 & 100 & 5 & 100 & 1 & 100 & 1 & 100 \\
\hline HDL (pr) & & & & & & & & \\
Tidak normal & 5 & 100 & 4 & 80,0 & 1 & 50 & 1 & 50 \\
Normal & 0 & 0 & 1 & 20,0 & 1 & 50 & 1 & 50 \\
\hline Total & 5 & 100 & 5 & 100 & 2 & 100 & 2 & 100 \\
\hline $\begin{array}{c}\text { Trigliserida } \\
\text { Tidak normal } \\
\text { (tinggi) }\end{array}$ & 10 & 100 & 9 & 90,0 & 3 & 100 & 3 & 100 \\
Normal & 0 & 0 & 1 & 10,0 & 0 & 0 & 0 & 0 \\
\hline Total & 10 & 100 & 10 & 100 & 3 & 100 & 3 & 100 \\
\hline
\end{tabular}

Berdasarkan tabel diatas, distribusi sampel berdasarkan tahap pretest dan posttest, pemeriksaan HDL laki-laki kelompok intervensi posttest terdapat $4(80 \%)$ yang tidak normal sedangkan pada pemeriksaan HDL perempuan kelompok intervensi posttest terdapat 4(80\%), variable trigliserida, kelompok intervensi pretst terdapat terdapat $10(100 \%)$ yang tidak normal dan pada post test terdapat $1(10 \%)$ yang normal.

Table 5 asupan zat gizi

\begin{tabular}{|c|c|c|c|c|c|c|c|}
\hline \multirow{2}{*}{ Kelomposk } & \multirow{2}{*}{ zatgizi } & \multicolumn{2}{|r|}{ Pre-test } & \multicolumn{2}{|c|}{ Post-test } & \multirow[t]{2}{*}{ AKG } & \multirow[b]{2}{*}{ Value } \\
\hline & & & Mean \pm SD & n & Mean $\pm S D$ & & \\
\hline \multirow{8}{*}{ Intevenens } & Lemak $(g)$ & 10 & $73,9500,9$ & 10 & $110,0+57,5$ & 539 & 0,112 \\
\hline & Proteing) & 10 & $67,9 \pm 31,5$ & 10 & $95,1 \pm 27,6$ & 579 & 0,950 \\
\hline & Karbohidrat (a) & 10 & $192,451,5$ & 10 & $254,6+322,7$ & 2859 & 0.007 \\
\hline & Vitamin $A(\nu g)$ & 10 & $233,3 \pm 117,6$ & 10 & $576,1 \pm 488,2$ & $600 \mathrm{mcg}$ & 0,055 \\
\hline & Vitamin C (mg) & 10 & $15,3 \pm 13,3$ & 10 & $26,8 \pm 16,9$ & $90 \mathrm{mg}$ & 0,028 \\
\hline & Vitamin B1 & 10 & $0.5+0.2$ & 10 & $12 \pm 0.2$ & $1.2 \mathrm{mo}$ & 0.00 \\
\hline & Vitamin B2 & 10 & $1,57 \pm 3,0$ & 10 & $1,1 \pm 0,34$ & 1,4 & 0,685 \\
\hline & Serat(g) & 10 & $6,67 \pm 2,86$ & 10 & $9,44 \pm 3,42$ & 28 & 0,072 \\
\hline \multirow{8}{*}{ kentrol. } & Lemak (g) & 3 & $50,6+35,7$ & 3 & $32,0 \pm 29,0$ & 539 & 0,588 \\
\hline & Protein(q) & 3 & $56,5411,3$ & 3 & $59,3+344,0$ & 570 & 0,912 \\
\hline & karkhohidrat(g) & 3 & $171,5+399,2$ & 3 & $147,1167,8$ & 2859 & 0,563 \\
\hline & Vitamin A (mg) & 3 & $871,6 \pm 1025,4$ & 3 & $696,1 \pm 455,9$ & $600 \mathrm{mcg}$ & 0,654 \\
\hline & Vitamin C (ma) & 3 & $8,7 \pm 5,008$ & 3 & $35,8 \pm 47,6$ & $90 \mathrm{mg}$ & 0,400 \\
\hline & Vitamin B1 & 3 & $0,5 \pm 0,1$ & 3 & $0,8 \pm 0,4$ & $1,2 \mathrm{mg}$ & 0,187 \\
\hline & Vitamin B2 & 3 & $0,5+0,5$ & 3 & $0,5+0,3$ & 1,4 & 0,868 \\
\hline & Serat(lo) & 3 & $7,211,5$ & 3 & $7,0 \pm 2,0$ & 28 & 0,968 \\
\hline
\end{tabular}

Berdasarkan table 5 menunjukkan bahwa zat gizi pretest pada kelompok intervensi yang mengalami perubahan signifikan setelah pemberian buah naga yaitu vitamin $\mathrm{C}$,karbohodrat, vitamin $\mathrm{B} 1$, sedangkan pada zat gizi serat nilai $p=0,072$ $(P>0,05)$ terjadi peningkatan namun tidak bemakna. Selain itu pada asupan zat gizi 
lemak yaitu terjadi peningkatan konsumsi lemak dengan nilai $p=0,112(p>0,05)$.

Table 6 Perubahan Pada Kelompok Intervensi Dan Kontrol PreTest Dan Post Test

\begin{tabular}{|c|c|c|c|c|}
\hline \multicolumn{5}{|c|}{ Intervensi } \\
\hline $\begin{array}{l}\mathrm{HDL}(\mathrm{mg} / \mathrm{dL} \\
\text { laki-laki }\end{array}$ & & & & \\
\hline Mean \pm SD & $40,80 \pm 5,54$ & $35,60 \pm 3,57$ & \multirow{2}{*}{$-5,2$} & \multirow{2}{*}{$0,225^{*}$} \\
\hline Min-Max & $34,00-49,00$ & $32,00-40,00$ & & \\
\hline \multicolumn{5}{|l|}{$\begin{array}{l}\text { HDL } \\
\text { Perempuan }\end{array}$} \\
\hline Mean \pm SD & $40.80 \pm 7,19$ & $41,80 \pm 1,13$ & \multirow{2}{*}{1} & \multirow{2}{*}{$1,00^{*}$} \\
\hline Min-Max & $31-50$ & $31-60$ & & \\
\hline \multicolumn{5}{|l|}{$\mathrm{TG}(\mathrm{mg} / \mathrm{dL})$} \\
\hline Mean \pm SD & $230,60 \pm 58,867$ & $238,40 \pm 97,416$ & \multirow{2}{*}{7,8} & \multirow{2}{*}{$0,717^{\star *}$} \\
\hline Min-Max & $166-320$ & $113-450$ & & \\
\hline \multicolumn{5}{|c|}{ Kontrol } \\
\hline \multicolumn{5}{|l|}{$\mathrm{HDL}$} \\
\hline Mean $\pm S D$ & $49,67 \pm 10,970$ & $49,00 \pm 11,269$ & \multirow{2}{*}{$-0,67$} & \multirow{2}{*}{$0,635^{\star *}$} \\
\hline Min-Max & $49,67 \pm 10,970$ & $49,00 \pm 11,269$ & & \\
\hline \multicolumn{5}{|l|}{$\mathrm{TG}(\mathrm{mg} / \mathrm{dL})$} \\
\hline Mean $\pm S D$ & $228,67 \pm 86,858$ & $213,67 \pm 56,128$ & & \\
\hline Min-Max & $167-328$ & $150-256$ & 15 & $0,158^{n}$ \\
\hline
\end{tabular}

Table 5 menunjukkan bahwa rerata perubahan HDL yang berjenis kelamin lakilaki pada kelompok intervensi yaitu pre-test 40,80 (mg/dL) dan post-test 35,60 (mg/dL) nilai $P=0,255>0,05$ tidak signifikan. Sedangkan rata-rata HDL pada perempuan pre-test $40.80(\mathrm{mg} / \mathrm{dL})$ dan post-test 41,80 $(\mathrm{mg} / \mathrm{dL}) \mathrm{p}=1,00>0,05$ tidak signifikan. Sedagkan rerata kadar TG kelompok intervensi mengalami peningkatan 230,60 menjadi 238,40 nilai $p=0,717 \quad(p>0,005)$ tidak ada pengaruh konsumsi buah naga terhadap penurunan kadar trigliserida.

Table 8 perbandingan kelompok intervensi dan kontrol

\begin{tabular}{llllll}
\hline \multicolumn{5}{c}{ Nilai mean \pm SD } \\
\hline & $n$ & intervensi & $n$ & kontrol & $p$ \\
\hline HDL & & & & & \\
Pretest & 10 & $40,80 \pm 6,05$ & 3 & $49,67 \pm 10,97$ & $0,088^{*}$ \\
postest & 10 & $38,70 \pm 8,59$ & 3 & $49,00 \pm 11,26$ & $0,077^{*}$ \\
\hline TG & & & & & \\
Pretest & 10 & $230,60 \pm 58,86$ & 3 & $228,67 \pm 86,85$ & $0,965^{*}$ \\
postest & 10 & $238,40 \pm 97,41$ & 3 & $213,67 \pm 56,12$ & $0,689^{*}$ \\
\hline
\end{tabular}

Berdasarkan hasil analisis dengan uji independent sampel test pada table 8 bahwa data yang diperoleh dari variable HDL pre-test kelompok intervensi dan kontrol nilai sign $=0,088 \quad(>0,05)$ dan sedangkan posttest nilaip $=0,077(>0,05)$. Artinya tidak ada perbedaan sebelum dan sesudah pemberian buah naga terhadap HDL pada kelompok intervensi dan kontrol, variable trigliserida pre-test kelompok intervensi dan kontrol nilai $p=0,965$, kelompok kontrol posttest nilai sign $p=0,689 \quad(p>0,05)$ maka tidak terdapat perbedaan rata-rata kolesterol hdl kelompok intervensi dan control.

\section{PEMBAHASAN}

1. Perubahan HDL dan Trigliserida

Table 5 menunjukkan rerata perubahan HDL yang berjenis kelamin lakilaki pada kelompok intervensi yaitu pre-test 40,80 (mg/dL) dan post-test 35,60 (mg/dL) dengan nilai $\mathrm{P}=0,255>0,05$ tidak signifikan. Sedangkan rata-rata HDL pada perempuan pre-test $40.80(\mathrm{mg} / \mathrm{dL})$ dan post-test $41,80(\mathrm{mg} / \mathrm{dL}) \mathrm{p}=1,00>0,05$ tidak ada perubahan yang signifikan.

Hasil penelitian ini sejalan dengan penelitian yang dilakukan oleh elnasari and ahmed (2008) bahwa rerata perubahan kadar HDL pada kelompok intervesi megalami penurunan dari 40,80 menjadi 38,70 yang secara statistik tidak signifikan.

Berdasarkan hasil pada penelitian ini pada kelompok intervensi terdapat $8(80 \%)$ responden yang mengalami sindrom metabolik yaitu obesitas sentral dan $5(50 \%)$ mengalami obesitas berdasarkan IMT dan 2 (20\%) yang mengalami overweight bedasarkan IMT. Penelitian sebelumnya oleh Jenny (2017) bahwa obesitas berhubungan dengan gangguan profil lipid. Kadar kolesterol HDL kelompok obesitas lebih rendah dibandingkan kelompok normal, terdapat korelasi IMT dengan kadar HDL rendah dan TG tinggi.

Meningkatnya IMT (overweight atau obese) disebut juga dengan adiposity disebabkan oleh meningkatnya akumulasi lemak (Zahra,2017). Fungsi adipogenesis (proliferasi dan differensiasi sel lemak) pada jaringan adiposa subkutan perifer, diikuti dengan terbatasnya ruang penyimpanan lemak di jaringan adiposa hal ini menyebabkan meningkatnya asam lemak bebas di sirkulasi. Meningkatnya asam lemak di liver menyebabkan meningkatnya sekresi VLDL yang kaya TG ke sirkulasi, hal ini menyebabkan meningkatkan konsentrasi TG dalam darah. VLDL ini akan mengalami reaksi pertukaran enzimatik dengan lipoprotein lain seperti HDL dan LDL dengan bantuan enzim cholesteryl ester transferase (CETP), akibatnya terjadi interaksi VLDL dengan lipoprotein lipase yang menyebabkan terbentuknya LDL yang lebih kecil dan padat (Bays,2013). Sedangkan HDL menjadi kaya akan trigliserida atau dikenal sebagai lipoprotein kaya trigliserida (TG). Apo A-1 dapat memisahkan diri dari HDL kaya trigliserida. ApoA-1 bebas ini 
segera dibersihkan dari plasma, melalui ginjal, sehingga mengurangi kemampuan HDL untuk reverse cholesterole transport. Akibatnya kadar HDL dalam darah menurun. Low density lipoprotein kaya trigliserida dapat mengalami lipolisis menjadi small dense LDL (Quin yu dkk, 2009).

Rerata kadar TG pada kelompok intervensi mengalami peningkatan nilai $p=0,717 \quad(p>0,005)$ yang berarti tidak ada pengaruh yang signifikan konsumsi buah naga terhadap penurunan kadar trigliserida.

Hal ini sejalan dengan penelitian terdahulu untuk rerata kadar TG pada kelompok intervensi mengalami peningkatan. Penelitian di sudan, pada 250 penderita $\mathrm{dm}$ menunjukkan peningkatan trigliserida serta penurunan hdl (elnasari, 2008). Kutsiah (2013) menunjukkan subjek yang memiliki kadar kolesterol tinggi cederung memiliki asupan serat yang lebih rendah di bandingkan dengan yang normal. Sementar itu subjek yang memiliki kadar trigliserida rendah cenderung memiliki asupan serat yang lebih tinggi dibandingkan dengan subjek yang memiliki kadar trigliserida tinggi.

Berdasarkan hasil foodrecall terlihat bahwa asupan serat kelmpok inervensi sebelum pemberian buah naga $6,6700 \pm 2,86009$ dan sesudah intervensi $9,7400 \pm 3,42027$.

Dalam penelitian ini kenaikan kadar trigliserida pada beberapa responden dikelompok intervensi dikarenakan konsumsi zat gizi khsusunya lemak lemak meningkat. Hal ini terjadi saat kami melakukan pencatatan foodrecall terhadap responden yaitu pretest dan post tesnya mereka mongkonsumsi makan berlemak lebih banyak. Triasilgliserol (TG) hampir 95\% dari makanan lemak (Gropper,2009).

2. Pengaruh konsumsi buah naga terhadap HDL \& Trigliserida

Berdasarkan hasil uji pengaruh pemberin buah naga terhadap kadar HDL post test kelompok intervensi dan kontrol memiliki sign $=0,077 \quad(>0,05)$, tidak ada perbedaan sebelum dan sesudah pemberian buah naga terhadap HDL pada kelompok intervensi dan kontrol.

Berbanding terbalik dengan penelitian yang dilakukan oleh Pertiwi \& Ratna (2014) bahwa Pemberian jus buah naga merah berpengaruh terhadap peningkatan kadar HDL pria dislipidemia pada kelompok perlakuan. Terdapat perbedaan kadar kolesterol HDL antara kelompok kontrol dan perlakuan setelah intervensi.

Pada penelitian ini, asupan lemak, karbohidrat, kolesterol dan vitamin C dikontrol karena dianggap dapat mempengaruhi kadar HDL. Selain itu asupan niasin dan antosianin juga dapat mempengaruhi kadar HDL, namun kedua zat gizi tidak dapat dianalisis karena keterbatasan software pengolah data.

Konsumsi karbohidrat juga mengalami peningkatan yang tinggi yaitu rerata pre test 192,4 sedangkan pos test 256,6 bahwa memang terjadi peningkatan yang sangat tinggi kosumsi lemak pda setiap responden.

Asupan lemak berlebihan serta rendahnya tingkat asupan vitamin $\mathrm{C}$ menjadi factor yang diyakini menyebabkan terjadinya penurunan HDL pada sebagian besar subjek. Faktor-faktor tersebut menjadi penghambat yang dapat mengurangi efektivitas pemberian buah naga merah dalam meningkatkan kadar HDL. Kadar kolesterol HDL dipengaruhi oleh modifikasi diet, asupan tinggi lemak jenuh dan kolesterol umumnya kadar HDL akan meningkat dan terjadi penurunan ketika asupan lemak diganti dengan karbohidrat. Karbohidrat menyebabkan penurunan $\mathrm{HDL}$ berhubungan dengan perubahan metabolisme Apo A-1 (Berglund L, et al.1999).

Kadar trigliserida tinggi terjadi ketika seseorang banyak mengonsumsi makanan yang mengandung karbohidrat atau kadar gula yang tinggi (GoffDC, et al,2006). Ratarata responden mengkonsumsi karbohidrat yang banyak antara pretest dan posttest yang mana nilai mean untuk pre test 192,4300 dan posttes meningkat menjadi 254,6900 .

\section{KESIMPULAN}

1. Tidak ada perubahan yang signifikan sebelum dan setelah megkonsumsi buah naga.

2. Tidak ada perbedaan yang signifikan sebelum dan setelah konsumsi buah naga.

\section{SARAN}

1. Diharapkan kepada peneliti selanjutnya untuk menambah dosis pemberian dan lama waktu pemberian konsumsi buah naga.

2. Diharapkan kepada peneliti selanjutnya untuk melakukan penelitian dengan sampel yang lebih banyak 


\section{DAFTAR PUSTAKA}

ADA. 2017. All About Cholesterol, http://www.diabetes.org/are-you-at-risk/lower-your-risk/cholesterol.html, diakses pada 19 october 2018.

Berglund L, et al. 1999. HDL-subpopulation patterns in response to reductions in dietary total and saturated fat intakes in healthy subjects. American Society for Clinical Nutrition, 1999;70:992-1000

Elnasri H.A. and Ahmed A.M, 2008. Patterns of lipid changes among type 2 diabetes patients in Sudan. Eastern Mediterranean Health Journal, Vol. 14, No. 2: 314-342

Goff DC, Bertoni AG, Kramer H, Bonds D, Blumenthal RS, Tsai MY, Psaty BM. 2006.Dyslipidemia Prevalence, Treatment, and Control in the MultiEthnic Study of Atherosclerosis (MESA): Gender, Ethnicity, and Coronary Artery Calcium American Heart Association, Inc, 113:647-656.

Gropper,S.S., Smith, J.L. and Groff.J.L. 2009. Advance Nutrition and Human Metabolism, Wadsworth; USA.

Jenny N.S,2017. Hubungan indeks massa tubuh dengan profil lipid serum sebagai faktor risiko penyakit kardiovaskuler pada mahasiswa universitas HKBP Nommensen, Nommensen Journal of Medicine Vol 3(1): 7-13

Nourah Faadlilah, ardiaria Martha, 2016, Efek Pemberian Seduhan Kulit Buah Naga Merah (Hylocereus Polyrhizus) Terhadap Kadar Hdl Tikus Sprague Dawley Dislipidemia, Journal of Nutrition College, Volume 5, (4): 280-288.

Pertiwi, W.A. \& Noer,E.R. 2014, Pengaruh Pemberian Jus Buah Naga Merah (Hylocereus Polyrhius) Terhadap Kadar HDL Pria Dislipidemia, Journal of Nutrition Collage, Vol 3 (4): 762-769.

Riset kesahatan dasar, 2013. Badan penelitian dan pengembangan kesehatan. Kementrian kesehatan RI.www.depkes.go.id

Saryono, 2011. Metodologi Penelitian Kesehatan, Mitra Cendikia: Jogjakarta.

WHO (World Health Organization) 2015.

WHO (World Health Organization) 2018.

Zahra dkk, 2017. Korelasi Indeks MassaTubuh dengan Profil Lipidd pada Masyarakat di Jatinangor tahun 2014. JSK, Vol 3 (1):12-17

Qin yu dkk, 2009, Anthocyanin supplementation improves serum LDL- and HDL-cholesterol concentrations associated with the inhibition of cholesteryl ester transfer protein in dyslipidemic subjects, Am J Clin Nutr, $90: 485$ 